\title{
A dialética do conflito ou como equilibrar interesses individuais e coletivos em uma comunidade cooperativa
}

The dialectics of conflict or how to balance individual and collective interests in a cooperative community

Dan Furukawa Marques ${ }^{1}$

Resumo: As Cooperativas de Produção Agropecuária (CPA) do Movimento dos Trabalhadores Rurais Sem Terra (MST) são consideradas por este como uma "forma superior de cooperação". A literatura sobre o assunto informa dados importantes e considera certas dinâmicas sociais e políticas internas às cooperativas. Porém, aprendemos pouco sobre as sutilezas das práticas cotidianas ou sobre como se criam e se desfazem os laços sociais e políticos no interior de uma cooperativa. Este artigo tem como objetivo apresentar uma aplicação prática de um conceito, a dialética do conflito, que busca analisar as práticas e discursos de sócios da cooperativa COOPAN do MST, com o objetivo de compreender as dinâmicas conflitantes, em movimento, e às vezes contraditórias, da construção de uma comunidade cooperativa.

Palavras chaves: dialética do conflito, práticas cotidianas, COOPAN, cooperativa, Movimento sem terra

1 Dan Furukawa Marques é professor no Departamento de Sociologia da Université Laval na cidade de Québec no Canadá. Ele é igualmente titular da Chaire de leadership en enseignement Alban D'Amours en sociologie de la coopération (CLEASC). Suas pesquisas se concentram sobre a construção de comunidades cooperativas e de movimentos sociais, da cooperação e de economias alternativas. 
ABSTRACT: The Agricultural Production Cooperatives (CPA) of the Landless Rural Workers Movement (MST) are considered by the latter as a "higher form of cooperation". The literature on the matter presents important data and considers social and political dynamics internal to the cooperatives. However, it does not focus its analysis on the subtleties of everyday practices and discourses or the way that social and political relations are crafted and undone inside a cooperative. This article aims at presenting a practical application of a concept, the dialectic of conflict, in order to analyze the practices and discourses of members of the MST's cooperative COOPAN with the goal of understanding the conflictual, moving, and sometimes contradictory dynamics of the construction of a cooperative community.

Keywords: dialectic of conflict, everyday practices, COOPAN, cooperative, Landless Movement

Desde o final dos anos 1980, as Cooperativas de Produção Agropecuária (CPA) do Movimento dos Trabalhadores Rurais Sem Terra (MST) são consideradas por este como uma "forma superior de cooperação" (MST, 1998). Impulsionado pelas possibilidades de se construir uma nova sociedade rural nos anos 1980 e 1990, o MST tentou difundir o modelo cooperativista em todos seus assentamentos. Inspirado principalmente pela experiência cubana, o Movimento sonhava em construir "ilhas socialistas" que criariam um "novo ser humano" (Jornal Sem Terra, vol. 102 : 3. Citado por Wright et Wolford, 2003: 310) dentro da sociedade capitalista brasileira (Novaes, Pires, et al., 2015). Esses espaços seriam considerados como "áreas liberadas" que, em função de sua estrutura econômica e política, estariam ao abrigo das crises e do governo² (Carter et Carvalho, 2015: 255; Branford e Rocha, 2003: 92). Apesar de um planejamento minucioso e uma vasta estrutura organizacional implementada, os problemas logo começaram a surgir,

2 O governo Collor (1989-1990) reduziu drasticamente os créditos agrícolas e a assistência técnica para a pequena agricultura, eliminando o Ministério da Reforma e do Desenvolvimento Agrário, despedindo funcionários do INCRA, reprimindo o MST com o exército, invadindo Secretarias estaduais do Movimento e apreendendo documentos de processos contra suas lideranças. Um dos resultados foi a queda de ocupações, passando de oitenta, em 1989, a quarenta e nove, em 1990. O número de famílias mobilizadas passou, no mesmo período, de 1.603 a 8.234 (Novaes, Pires et al., 2015: 113). 
e essa iniciativa se tornou um fracasso (CONCRAB, 1998; Panhke, 2015: 1099). Em todo o país, a grande maioria das CPA se endividaram demasiadamente e centenas de famílias decidiram abandonar 0 projeto e voltar a investir em uma produção individual de subsistência. Porém, existem cooperativas que vingaram e que, até hoje, são muito bem sucedidas, tendo se tornado verdadeiros modelos de organização coletiva do trabalho para o MST, como é o caso da COOPAN que analisaremos em detalhe no presente artigo.

Os estudos sobre as CPA do Movimento se concentram em fatores principalmente contextuais, organizacionais, estruturais ou ideológicos, mobilizados em análises que raciocinam em termos sobretudo de "sucesso" ou de "fracasso" das experiências cooperativas. Ainda que essas análises informem dados importantes e considerem certas dinâmicas sociais e políticas internas às cooperativas, elas nos ensinam pouco sobre as sutilezas das práticas cotidianas ou sobre a maneira como se criam e se desfazem os laços sociais e políticos no interior de uma cooperativa. Este artigo tem como objetivo apresentar uma aplicação prática de um conceito, a dialética do conflito, que busca analisar as práticas dos atores e suas histórias pessoais, com o objetivo de compreender as dinâmicas conflitantes, em movimento, e às vezes paradoxais, da construção de uma comunidade cooperativa. Como entender $\mathrm{o}$ caráter político ${ }^{3}$ das cooperativas enquanto comunidades de trabalhadores regidas por normas dominantes e um projeto social? Como pensar a relação e as contradições entre as aspirações e desejos individuais e as necessidades coletivas dentro das práticas co-

3 Retomo aqui a definição e distinção "du politique" (utilizarei o termo "o" político no presente artigo) com relação à "la politique" ("a" política) tal como a entende Claude Lefort (1986). De forma geral, Lefort define o político ou a dimensão política da existência humana como a "forma da sociedade" ou o "regime", no sentido grego do termo. Em outras palavras, o político é um processo através do qual se edificam as normas, os valores e as instituições. A forma que toma uma sociedade se constrói a partir da adoção pelos sujeitos, de maneira consciente ou não, de normas, princípios e práticas. No entanto, o processo que permite o compartilhamento de significações comuns que, em última instância, criam uma normatividade social, nem sempre é pacífico ou consensual. Ao contrário, esse processo ou mecanismo de criação de princípios de ordem que orientam as instituições sociais é, na maioria dos casos, o de confronto de ideais, de perspectivas, de visões e experiências do mundo. A dimensão propriamente política da coexistência humana é então a forma que toma uma sociedade instituída pelo conflito. 
tidianas, muitas vezes influenciadas por limitações socioeconômicas impostas pela economia de mercado? Avanço aqui algumas respostas a estas questões pelo que chamo de processo de instituição política de uma comunidade cooperativa a partir de um estudo de caso, a Cooperativa de Produção Agropecuária Nova Santa Rita (COOPAN), pertencente ao $\mathrm{MST}^{4}$.

\section{ESTRUTURA DO ARTIGO E CONSIDERAÇÕES TEÓRICAS}

Este artigo se divide em três partes. A primeira parte apresenta uma breve revisão da literatura para situar o tipo de pesquisa produzida sobre as cooperativas do MST. A segunda parte apresenta uma história dos primeiros anos da COOPAN (de 1994 a 2002-2003), que representa o período materialmente mais difícil de construção da comunidade, até a cooperativa se consolidar economicamente. Essa história é mais detalhada e segue uma ordem cronológica graças à excelente memória de meus interlocutores que souberam me contar com precisão as diferentes etapas - e sobretudo os conflitos e obstáculos - desse período. A terceira parte apresenta uma série de conflitos ditos "estruturantes" (segundo as palavras de Emerson), que ocorreram principalmente entre 2003 e 2014. Na memória dos entrevistados, esse período é muito menos claro e preciso, e foi difícil para eles reconstituir uma história dos eventos ocorridos. Entretanto, um deles, Emerson, soube testemunhar sobre a história da cooperativa com impressionante precisão e clareza. Completando sua entrevista com informações tiradas de outros sócios da COOPAN, apresentarei uma análise da construção da comunidade cooperativa COOPAN através do que chamei de dialética do conflito. Em outras palavras, a segunda parte apresenta uma história ou uma trama narrativa, evidenciando as dimensões de experimentação, de estruturação e de organização do que se tornará

4 Para esse estudo foi realizada uma pesquisa de campo que se estendeu sobre um período de cinco anos (janeiro de 2013 a junho de 2017), dezoito meses de pesquisa etnográfica, e quatro anos como professor de um curso de pesquisa de campo em comunidades do MST no Brasil, onde levei vários grupos de estudantes canadenses. 
a orientação política geral da forma do trabalho e da vida coletiva. A terceira parte expõe uma série de conflitos que esclarecem a análise do frágil e necessário equilíbrio entre coletivização e individualização próprio, à coexistência das famílias da COOPAN.

A dialética do conflito constitui a grade de análise a partir da qual foram destacados os eventos que permitem compreender essa dialética: de um lado os conflitos, entendidos como desentendimentos (Rancière, 1995) intersubjetivos sobre a maneira de gerenciar a coexistência (Lefort, 1986) no interior da cooperativa e da vida comunitária; do outro lado, a unidade ou superação (às vezes temporária) do conflito, ou seja, soluções práticas (o que os sócios chamam de "procedimento") tanto da cooperativa quanto da vida comunitária em geral, que eles "inventam" através da "força do coletivo". Assim, nessa reconstrução temporal da história da COOPAN, tentei colocar em evidência os principais obstáculos encontrados ao longo de vinte e quatro anos de existência e as maneiras de superá-los. O que proponho aqui é uma história de eventos suficientemente significativos para fazerem aparecer, num primeiro momento, a dimensão política no seu aspecto conflitante, seguida pelo aspecto unificador, em seguida, permitindo, a cada vez, reafirmar princípios políticos cardinais que surgem através de práticas e espírito coletivos.

\section{O "FRACASSO" DAS COOPERATIVAS NA LITERATURA}

Nesta primeira parte, farei uma breve categorização do tipo de abordagem teórica que encontramos na literatura científica sobre o assunto das cooperativas. Os autores Sue Branford e Jan Rocha (2002) atribuem o fracasso de várias cooperativas do MST ao fato de que os trabalhadores rurais tiveram muita dificuldade em aceitar o trabalho coletivo e a coletivização das terras de produção. Para muitos dentre eles, o sonho era simplesmente obter um pedaço de terra para produzir e melhorar as condições de vida. Em outras palavras, o fracasso se explica principalmente por discordâncias ideológicas entre as aspirações e mentalidades tradicionais das famílias, e a vontade do Movimento. 
Os sociólogos Farid Eid et al. (2015), explicam o fracasso pelos seguintes fatores: muita terra desapropriada em regiões onde viver de agricultura é quase impossível (má qualidade do solo, dificuldade de plantação e comercialização, más condições de estrada, falta de acesso à eletricidade e a esgotos, etc.) (Eid et al., 2015: 135-136). Em outros termos, são fatores contextuais que explicam o fracasso.

Segundo uma série de autores - Christoffoli (1998), Pimentel (2004), Vazzoler (2004), Eid et al., (2006), Severino (2006) e Chiariello (2008) - uma das maiores dificuldades das cooperativas consiste em realizar a transição de uma produção agrícola familial não mecanizada para uma produção agroindustrial, um processo de aprendizagem muitas vezes tenso, com acertos e falhas. Os motivos do fracasso são, portanto, de ordem organizacional, uma gestão ineficaz e falta de conhecimento individual.

Wilder Robles e Henry Veltmeyer (2015: 109), num estudo importante e recente sobre as cooperativas do MST, privilegiam uma abordagem mais estrutural. Eles ressaltam que o governo de Fernando Henrique Cardoso foi igualmente responsável através dos cortes nas políticas agrícolas e dos atrasos consideráveis na obtenção de créditos agrícolas e de assistência técnica. Eles reconhecem os erros de organização, mas afirmam que o problema econômico estrutural de falta de acesso adequado às políticas públicas é a causa principal do fracasso das cooperativas (Robles et Veltmeyer, 2015: 147).

Em suma, podemos classificar as análises do fracasso em quatro fatores explicativos: ideológico (os sem-terra aspiravam à autonomia individual ao invés do trabalho coletivo); contextual (as terras desapropriadas não eram adequadas à construção de cooperativas); organizacional (dificuldade de organização do trabalho e falta de conhecimento); estrutural (falta de apoio do Estado). Embora todas essas análises avancem argumentos importantes, nenhuma delas leva em consideração a trajetória completa da comunidade, a história de vida das famílias, as práticas cotidianas, assim como o funcionamento atual delas - em outras palavras, não tentam compreender a construção de uma comunidade cooperativa em um longo período, nem seu aspecto propriamente político. A etnografia permite justamente uma 
apreciação das experiências sociais e políticas vividas pelos membros do grupo. O objetivo aqui é examinar a importância das práticas coletivas na viabilidade da cooperativa, tanto na maneira como o espírito cooperativista perdura e se transforma, quanto na maneira como o trabalho é organizado cotidianamente.

\section{FUNDAÇÃO DA COOPAN: UM IDEAL COMUM NA DIFERENÇA5}

Em maio de 2018, a Cooperativa de Produção Agropecuária Nova Santa Rita (COOPAN) comemorava seu $24^{\circ}$ aniversário. Mas as trinta e uma famílias que compõem a cooperativa percorrem o mesmo caminho desde 9 de setembro de 1989, data de sua primeira ocupação de terra, a experiência política fundadora de suas vidas de Sem Terra. Para o MST, a COOPAN representa um modelo de sucesso socioeconômico de uma cooperativa inteiramente administrada segundo o modelo do "trabalho coletivo". Ela serve de "vitrine" ao Movimento, a fim de mostrar para a população brasileira e para as autoridades públicas, a capacidade dos trabalhadores rurais de construírem uma comunidade estável, economicamente viável, respeitando os princípios ambientais da agroecologia, e onde o trabalho e a vida cotidiana são organizados de maneira coletiva e democrática. Além disso, as escolas e formações políticas, desenvolvidas ao longo dos anos no assentamento e na região, servem igualmente de exemplos para o Movimento. Porém, como veremos a seguir, para chegar a esse nível de desenvolvimento, as famílias da COOPAN tiveram que enfrentar diversos desafios, e inventar diferentes maneiras de manter seus prin-

5 Ao longo de minha pesquisa de campo, visitei quatorze cooperativas em quatro estados brasileiros. A organização da produção, a divisão do trabalho, a comercialização, os tipos de produtos, a distribuição e a repartição das terras, o posicionamento das casas, as refeições e os espaços coletivos, são todos pensados e decididos coletivamente e, portanto, variam, às vezes de maneira considerável, de uma cooperativa a outra. Tive a oportunidade de visitar diversas cooperativas no Rio Grande do Sul e no Paraná, que são mais parecidas, provavelmente devido à experiência sócio-histórica semelhante dessas populações, de seus passados de imigrantes agricultores europeus, da forte influência dos padres progressistas da Igreja Católica, e de seu modo de vida familial (ver Wolford, 2010 e Bleil, 2012). 
cípios sociais e políticos, ao mesmo tempo em que estruturavam economicamente a cooperativa.

Ainda no "tempo de acampamento" (Rangel Loera, 2006), as famílias que mais tarde comporiam a COOPAN estavam reagrupadas, junto com outras cem famílias, em um "grupo de trabalho" chamado Grupo dos Gringos. Por motivos que veremos abaixo, o Grupo dos Gringos foi o último a conquistar terra. O tempo "extra" passado no acampamento foi dedicado a discutir e a planejar ao máximo a organização do assentamento: desde a organização da produção, passando pela educação, até a disposição das casas. Esse tempo se acrescentou aos quatro anos de acampamento durante os quais os grupos de trabalho se reuniam "ao menos uma vez por semana" para planejar o assentamento. Emerson conta que, em uma ocasião, um militante veio para dar uma formação e ele se lembra de ter perguntado: "Mas como vamos montar uma cooperativa do nada? Do nada! Nós não temos nada, nenhuma ferramenta, nada..." (Entrevista com Emerson ${ }^{6}, 3$ maio 2013). O militante, um morador de um assentamento com trabalho coletivo, explicou calmamente o jeito de se organizar por setores de produção, o ajustamento das horas de trabalho, a repartição das sobras, etc. "As pessoas começaram a gostar porque era alguém de uma cooperativa, um camponês como elas, que vinha falar de coisas que ele mesmo vivia" (Entrevista com Emerson, 3 maio 2013). Em outras palavras, havia um trabalho de construção de um imaginário coletivo pelo método "camponês a camponês", muito valorizado hoje em dia na abordagem agroecológica (ver Holt-Gimenez, 2008).

Apesar de todos esses esforços, uma vez a terra conquistada, a implementação do projeto de cooperativa desenvolvido durante o tempo de acampamento acabou se tornando muito mais complexa do que se tinha antecipado. Ao contrário do que deixam entender Robles e Veltmeyer (2015: 151), não é porque os camponeses discutiram, exaustivamente, o projeto de trabalho coletivo no futuro assentamento, que a cooperativa vai necessariamente se edificar facilmente. Evidentemen-

6 Por motivo de fidelidade ao contexto da pesquisa de campo, todos os nomes citados dentro do texto correspondem aos apelidos dos entrevistados. A correspondência entre o apelido e o nome verdadeiro se encontra no final do artigo. 
te, as numerosas formações, discussões e reuniões em volta do projeto, durante os anos de acampamento são extremamente importantes. Mas isso não significa que os desafios para implantar o projeto não sejam consideráveis. Na realidade, os sem-terra tendem a subestimar a amplitude da tarefa que os aguarda. Por exemplo, bem que o projeto comum do Grupo dos Gringos era baseado na ideia de trabalho coletivo, existiam, dentro do Grupo, várias maneiras de pensar a cooperativa e a organização concreta do trabalho coletivo, gerando muitas divergências e debates. Em outras palavras, o imaginário coletivo se desdobra em um ideal comum, mas dentro de uma práxis diferenciada segundo as subjetividades que nela participam. Entretanto, Zanete lembrava, com razão, que as "divergências sempre existirão. Mas a gente pensava assim: se tu tem um problema sozinho, vai resolver sozinho. Mas se somos dez, então seremos dez nos ajudando" (Entrevista com Zanete, 25 março 2013).

Espaços comuns de entendimento são possíveis, contanto que o espírito coletivo se sobressaia com relação aos desentendimentos subjetivos - sem apagá-los. Em contrapartida, esse espírito coletivo deve reconhecer seus limites. Se ele colide demasiadamente com as liberdades individuais, ele será ameaçado. Se seu efeito é desresponsabilizar os indivíduos, ele se desmoronará. O importante é lembrar-se da escolha comum de trabalhar coletivamente, sempre tentando equilibrar esse princípio com as aspirações e desejos individuais. A esse respeito, Emerson recorda o fracasso estratégico do MST afirmando que

o Movimento cometeu um grave erro de metodologia. Tinha bastante gente de cooperativas que vinham no acampamento dar formações sobre cooperativas [...] e não sobre cooperação. Tinha um foco muito grande em como construir uma cooperativa e acabamos perdendo de vista o mais importante que era como trabalhar em cooperação. A cooperativa é só um jeito de trabalhar em cooperação (Entrevista com Emerson, 3 maio 2013).

Ainda que a experiência coletiva do acampamento tenha sido essencialmente a mesma para a maioria dos indivíduos envolvidos, ela se traduziu por expressões subjetivas particulares. Encontrava-se as- 
sim, de um lado, as famílias que acreditavam no trabalho coletivo, que haviam sido sensibilizadas, mentalmente e afetivamente, por certos princípios e práticas políticas durante o acampamento; e, de outro lado, aquelas famílias que idealizavam o sonho de "ter paz", quer dizer, de "ter uma pequena terra, uma pequena casa e plantar meus legumes e que me deem sossego. É pedir muito?" (Entrevista com Wanderley, 4 setembro 2013). Essa constatação de mentalidades divergentes tinha sido feita por aqueles que acreditavam na cooperação desde a formação e consolidação do Grupo dos Gringos. Entretanto, mesmo sabendo que certas famílias que participariam da construção da COOPAN não tinham realmente a sensibilidade afetiva, nem o espírito adequado para o trabalho coletivo, os cooperativistas decidiram manter todas essas pessoas no grupo. Foi uma decisão consciente, e tomada em função de um princípio político forjado no acampamento que, de um lado, comanda uma atitude de ajuda-mútua e de compartilhar o pouco que têm e, do outro, de acolher as divergências e os conflitos. A aceitação das diferentes maneiras de apreender uma coexistência ancorada no trabalho coletivo, ou até mesmo a aceitação da recusa desse trabalho coletivo, significa, mais fundamentalmente, a instauração de um processo de interrogação permanente sobre a forma da comunidade que está se construindo.

O resto da história ilustra essa atitude e essa consciência, esse estado de espírito orientado por um ideal comum, mas abraçando voluntariamente a diferença. Depois de quatro anos de acampamento, o Grupo dos Gringos ${ }^{7}$ acaba se instalando na terra onde está localizada a COOPAN, perto do município de Nova Santa Rita, a $40 \mathrm{~km}$ de Porto Alegre. O Grupo foi o último do acampamento a conquistar terra, porque era um grupo muito grande (cem famílias), e as terras desapropria-

7 Do acampamento saíram, no final, quatro grupos de trabalho (incluindo o Grupo dos Gringos), prontos a construir uma cooperativa. Hoje só restam dois. O primeiro a receber a terra foi instalado perto do município de Livramento, mas "eles só queriam ganhar no sorteio", ou seja, "eles não tinham um projeto montado de cooperativa, nem talvez a vontade mesmo de construir uma". Muito rapidamente, o projeto não funcionou. Em seguida, teve o grupo de Piratini que funciona ainda hoje, mesmo se em pequena escala. Enfim, o grupo de Eldorado durou um certo tempo, mas acabou se desfazendo igualmente (Entrevista com Airton, 25 março 2013). 
das pelo governo, na sua maioria, não acomodavam todas as famílias. Foi por esse motivo que o Grupo decidiu, coletivamente, não participar dos sorteios de terras que não poderiam acomodar o grupo todo. Eles não queriam se dividir ou deixar famílias para trás, mesmo se tivessem que esperar mais. Em outras palavras, independentemente da falta de consenso sobre a vontade de trabalhar coletivamente - razão de ser do grupo - as cem famílias decidiram abdicar da possibilidade de conquistar terra mais rapidamente, em nome da solidariedade entre elas: "a gente não deixava ninguém pra trás" (Entrevista com Airton, 25 março de 2013).

A terra que o grupo acabou conquistando pertencia a um médico e empresário que possuía "várias dúzias" de terras equivalentes $(2,240$ ha) espalhadas pelo Brasil. Seu plano era desenvolver uma plantação de cana de açúcar para produzir etanol. "Uma verdadeira piada”, explica Marcon, o principal negociador do MST para essa terra, "qualquer um que tinha o mínimo de conhecimento em agricultura, batia o olho na terra e percebia imediatamente que era impossível plantar cana nesse solo de várzea" (Entrevista com Marcon, 23 junho 2013). O projeto foi de fato um fracasso, e o proprietário se endividou muito no Banco do Brasil. O Instituto Nacional de Colonização e Reforma Agrária (INCRA) acabou negociando com o proprietário para compensá-lo financeiramente, o que lhe permitia pagar suas dívidas, além de fazer um lucro espetacular de $\$ 400.000$ dólares americanos ${ }^{8}$.

Oito pessoas (uma ou duas famílias) moravam nas terras quando os sem-terra chegaram. Elas trabalhavam para o proprietário, tentando, de maneira infrutífera, plantar cana de açúcar. Havia também trezentas cabeças de gado, mais ou menos 40 a 50 ha de arroz plantado, e algumas árvores. As duas famílias foram convidadas pelos sem-terra a permanecerem na terra, e a se tornarem sócias da cooperativa. Mesmo tendo recusado o convite, elas ainda moram na terra. Além disso, a escola primária Ruy Barbosa, localizada no terreno, que foi frequentada por todos os jovens da COOPAN, estava fechada à época. Os

8 Marcon acrescenta que hoje o hectare de terra vale muito mais do que naquela época, pois a localização valorizou muito, estando a apenas $40 \mathrm{~km}$ de Porto Alegre. 
seguintes números, segundo Marcon, mostram o resultado concreto da reforma agrária:

Antes tinha oito pessoas, trezentas cabeças de gado, um pouco de arroz e uma escola fechada. Hoje, cerca de seiscentas pessoas vivem no assentamento. A escola está aberta desde 1994 [ano da conquista da terra] e cerca de 600 ha de arroz estão plantados. Então, independentemente da questão da produção, a questão social em si justifica a reforma agrária ${ }^{9}$ (Entrevista com Marcon, 23 junho 2013).

Esses fenômenos operam de fato uma transformação social da terra, a ocupação de um território quase sem vida que se torna um espaço coletivo onde centenas de indivíduos moram, trabalham e educam seus filhos ${ }^{10}$.

\section{OS PRIMEIROS PASSOS COOPERATIVISTAS: ENTRE SACRIFÍCIO PESSOAL E BEM COMUM}

Uma vez que a terra foi regularizada e se tornou assentamento,

A primeira grande discussão foi a distribuição da terra. Tinha quatro grandes parcelas [no assentamento]. Os grupos se for-

9 Marcon também negociou todos os programas de ajuda governamental no começo da cooperativa: "Tinha a secretaria e eu cuidava das finanças do Movimento e dos acordos com os governos para lançar a produção. Acordos de assistência social com Itamar Franco, por exemplo. Tinha recursos do Caritas Holanda, Caritas Bélgica. Meu trabalho era ir buscar dinheiro e participar das negociações. Participei da negociação com Simão e depois Lares, quando eram governadores. O único [acordo] que não estava foi com o Brito. Um número incalculável de audiências com ministros a nível nacional. Foram muitas negociações antes que me torne deputado" (Entrevista com Marcon, 23 junho 2013).

10 De forma geral, os problemas e desafios que a COOPAN teve que enfrentar durante os primeiros anos da cooperativa (em termos de qualidade da terra, de posicionamento das casas, de divisão de trabalho, de gestão coletiva, de insuficiência de postos de trabalho, de adaptação a novas tecnologias, de dificuldades de comercialização, etc.) se parecem muito com a situação em que vivem a maioria das cooperativas Para uma análise detalhada ver Christoffoli, 2000. 
maram e distribuímos as parcelas ${ }^{11}$. Tinha o grupo Santa Maria [cerca de dez famílias], Santa Clara [cerca de vinte famílias], Birubaque [cerca de dez famílias] e a COOPAN [cinquenta e oito famílias]. Cada grupo discutia a maneira de distribuir os lotes dentro de sua parcela. As famílias se ajustavam e mudavam de lugar de acordo com as discussões (Entrevista com Emerson, 3 maio 2013).

A COOPAN logo diminuiu para cinquenta e três famílias pois cinco deixaram o grupo e foram se instalar individualmente. Essa perda inicial de famílias revelou o problema de ocupação do espaço.

Geralmente, quando os sem-terra conquistam a terra, o INCRA delimita o território em lotes de terra que são distribuídos individualmente às famílias. Elas podem, a partir daí, organizar o lote como bem entenderem. Por exemplo, se a organização da produção for individual, elas morarão e plantarão dentro de seus lotes. Nesse caso, dependendo da extensão do espaço, as casas das famílias podem se encontrar a centenas de metros, ou até mesmo quilômetros, umas das outras. Ao contrário, as famílias inspiradas pelo projeto de trabalho coletivo decidem colocar em comum todo o espaço dedicado à plantação, para, em seguida, designar um segundo espaço para a habitação. O primeiro espaço é coletivo, o que significa que todas as famílias devem ceder à cooperativa (ou à associação) sua parte de terra destinada à produção.

No caso da COOPAN, o problema de ocupação do espaço surgiu quando uma família decidiu deixar a cooperativa, em um momento em que eles ainda não tinham planejado qual parte do espaço de plantação seria entregue para essa família. Emerson conta que certas famílias não deixavam a cooperativa simplesmente porque tinham medo de acabar num terreno ruim ${ }^{12}$. Para resolver esse problema, os sócios chamaram o INCRA para que ele delimitasse todo o território da COOPAN em

11 As cem famílias do Grupo dos Gringos se dividiram nesses quatro grupos quando conquistaram a terra.

12 Um terreno com um solo de menor qualidade, mais difícil de acesso, sem sistema de esgoto, sem canalização de água, etc. 
lotes individuais (como se esse território não fosse coletivo), levando-se em conta a igualdade de acesso à canalização de água, de estradas, de caminhos de terra e de esgoto. Assim, qualquer família que decidisse deixar a cooperativa saberia exatamente para onde ela seria deslocada e todo o processo seria justo. Desse jeito, a cooperativa se assegurava de que cada lote de terra fosse de qualidade igual ao espaço comum. Eles então escolheram

[...] oito ou nove lotes de terra para famílias que sairiam para que elas já saibam o que as esperava e para que a cooperativa não precise repensar toda a produção cada vez que isso acontecesse. Era um jeito para nos de garantir que as famílias que escolhessem ficar na cooperativa o fizessem porque acreditavam no projeto e não porque tinham medo de acabar ficando num terreno ruim. O lote de terra é uma conquista de cada família e elas têm o direito a uma terra de qualidade tanto quanto nós (Entrevista com Emerson, 3 maio 2013).

A COOPAN então planejou os mínimos detalhes de um plano de saída de famílias que decidissem abandonar o projeto, para que elas pudessem saber exatamente o que esperar, e ter certeza de que não seriam penalizadas em termos de qualidade de terreno. Foi a primeira experiência de resolução de conflito interpessoal e coletivo pela criação de um "procedimento" padronizado, transparente e justo. Depois desse planejamento, algumas famílias deixaram a cooperativa, mas o número de sócios se estabilizou. "É esse tipo de mudança que foi feito ao longo de todo o processo de construção da cooperativa e que foi decisivo" (Entrevista com Emerson, 3 maio 2013). Esse primeiro conflito mostra a vontade dos cooperados de neutralizar possíveis instrumentos de poder que poderiam exercer sobre algumas pessoas, no caso, aquelas que não acreditavam totalmente no projeto de trabalho coletivo. Essa ação tinha como efeito reforçar o estabelecimento de uma verdadeira orientação política, fundada na convicção em seguir princípios de coexistência social não por obrigação, mas por acreditar no interesse coletivo, no bem da comunidade. 
A segunda grande decisão de importância foi a de investir na agroindústria. Gerar postos de trabalho. Porque no começo nós tínhamos muita mão de obra e poucos postos de trabalho, então não conseguíamos gerar lucro. Demorou mais ou menos um ano para regularizar o abatedouro que foi nossa primeira agroindústria. Essa decisão, essa avaliação, que ressalta que é a agroindústria que gera lucro e postos de trabalho foi fundamental para a cooperativa. Então, desde o começo, a cooperativa sempre, sempre, sempre colocou o foco nisso. Nós criamos essa cultura de agroindústria (Entrevista com Emerson, 3 maio 2013).

Com efeito, desde o começo, todos os sócios se entenderam sobre o fato de que as sobras financeiras geradas pela venda da produção deveriam ser orientadas para o investimento de base, no maquinário e nos caminhões, para construir a agroindústria. Essa decisão implicava sacrifícios pessoais importantes, podendo ir até à alimentação: "Nós tínhamos mais fome no começo do assentamento do que no acampamento" (Entrevista com Romeu e Elenice, 21 junho 2013). Os primeiros anos serviram de experimentação para testar a implantação de vários setores de produção. Emerson diz que os cooperados estavam muito "dispersos", e que um reajustamento era necessário. Eles possuíam os setores de horta, animais, gado de corte, leite, porcos e aves. Na época, e principalmente ao longo dos dez primeiros anos da COOPAN, professores e estudantes da Universidade Federal do Rio Grande do Sul (UFRGS) e da Pontifícia Universidade Católica do Rio Grande do Sul (PUC-RS), assim como militantes agrônomos e alguns técnicos agrícolas da Empresa de Assistência Técnica e Extensão Rural (Emater), prestaram uma assistência crucial à COOPAN ${ }^{13}$. Todas essas pessoas contribuíram com

13 Romeu acrescenta: "Eles te mostravam o que que tinha futuro [em termos de escolha de produção e de organização]: 'se vocês superarem isso, vocês vão chegar naquilo'. A gente sempre planejava para cinco anos: 'em cinco anos a gente quer atingir a meta de quinze porcos abatidos por dia'. E eles falavam: "olha, quando vocês chegarem a cem porcos por dia, vai faltar mão de obra pra trabalhar'. E a gente dizia: 'a gente gostaria de ter uma casa, um carro e um salário mínimo'. E eles respondiam: 'quando vocês tiverem uma casa, um salário mínimo e quinze porcos [abatidos] por dia, vocês vão estabilizar e talvez começar a regressar se vocês não planejarem perfeitamente o que virá depois'. Eles nos ajudaram muito nos forçando a enxergar mais longe, a planejar a longo prazo" (Entrevista com Romeu, 21 junho 2013). 
o planejamento da produção, a viabilidade econômica dos projetos e o desenho da planta da agrovila. Esta última constitui o espaço de habitação formando um tipo de um bairro onde são construídas todas as casas, a rede de eletricidade, o escritório, a Ciranda (espaço educativo para as crianças), o refeitório, o ginásio, os campos de futebol, as hortas comunitárias e pomares de frutas. Assim, a construção da comunidade também foi igualmente um trabalho intercomunitário, fruto do apoio prático de diversos indivíduos, incluindo a população local que acreditava no potencial desses camponeses.

No seu começo, a COOPAN teve que enfrentar vários desafios de ordem administrativa e de organização da produção. A maioria dos sócios era oriunda de uma região onde a principal cultura agrícola era a soja e o milho, e seus pais sempre tiveram criação de suínos. A grande maioria dos agricultores produzia leite, nem que fosse só para consumo próprio. Eles sempre tinham a produção de suínos associada ao milho, alimentação para os porcos e as vacas. Além disso, "para a subsistência, tínhamos que ter milho. Era cultural. Não conseguíamos nos imaginar sem produzir milho. Meu pai me ensinou: se um dia você não tiver mais milho, não vai dar certo. Então até a gente quebrar a cara, nós não íamos desistir" (Entrevista com Emerson, 3 maio 2013). Eles tinham também essa "convicção ingênua" segundo a qual o fato de serem todos filhos de pequenos agricultores faria com que eles soubessem imediatamente o que fazer com a terra. Eles estavam longe da realidade.

Quando chegaram, apesar "da terra bem diferente, vermelha ou preta e não arenosa, além de estar totalmente degradada [por conta do fracasso da produção de cana de açúcar]" - foi essa sabedoria familiar que tentaram colocar em prática (Entrevista com Zanete, 25 março 2013). Por esse motivo, os chiqueiros foram as primeiras instalações a serem construídas. No primeiro ano, apesar do aviso explícito dos técnicos consultados, eles plantaram um pouco de soja e 150 ha de milho. A colheita foi quase inexistente, pois o solo não era nem um pouco propício a esse tipo de cultura. No segundo ano, eles decidiram seguir os conselhos dos especialistas e se lançaram na produção de arroz. Ironia do acaso, eles perderam quase toda a colheita por 
conta de uma chuva de pedra que destruiu $80 \%$ das lavouras ${ }^{14}$. Eles tinham feito um empréstimo no Banco do Brasil e, desde o segundo ano, contraíram uma dívida de $\$ 26.000$ reais. No terceiro ano, tudo foi destruído de novo, mas desta vez por uma inundação provocada por um alto nível (inabitual) de chuva. Esses três primeiros anos de fracasso, onde perderam o maior número de sócios que desistiram do projeto, demonstram também a capacidade de trabalho e a resiliência dessas famílias ${ }^{15}$.

É nesse momento que os sócios perceberam que deveriam continuar a "se organizar [politicamente] para obter recursos, senão, não conseguiremos produzir"16. Tínhamos que continuar na luta. Foi o nosso primeiro conflito" (Entrevista com Zanete, 25 março 2013). Na verdade, o conflito era duplo. De um lado, havia a pressão política que os sem-terra deveriam começar a exercer novamente sobre o governo. Do outro, e mais fundamentalmente, esse conflito era igualmente de ordem interna ou intrasubjetiva, entre a crença no projeto de uma cooperativa e os resultados mitigados obtidos até então. Tinham que manter o moral, a motivação, a crença de que o projeto funcionaria um dia. Foi nesse momento que um elemento extracomunitário entrou em cena $\mathrm{e}$ contribuiu, de maneira significativa, para trazer de volta a esperança e a confiança no projeto cooperativo: as frequentes visitas, provenientes

14 Um seguro do Instituto do Arroz do Rio Grande do Sul (IRGA) permitiu minimizar os estragos financeiros.

15 "Nós não tínhamos nem um balde d'água para dar banho nas crianças" (Entrevista com Fatima, 22 junho 2013).

16 Para informação, Carter resume o período de 1996-2006, com relação à evolução do MST no Rio Grande do Sul e de sua relação com o governo federal e a sociedade civil, da seguinte forma: "All in all, the period between 1995 and 2006 offered improved conditions for the land struggle in this state, notwithstanding the large obstacles in place for land redistribution. Because of great MST pressure and state response, the pace of land reform increased considerably between 1996 and 2002. During this time, the federal and state governments created two-thirds of all land reform settlements established in Rio Grande do Sul from 1979 to 2006. [...] Opinion polls taken in April 1997 showed that $94 \%$ of the population felt the struggle for agrarian reform was just, whereas $85 \%$ indicated support for nonviolent land occupations as a way to accelerate government reform efforts" (Carter, 2015: 165). 
de todo o Brasil, e mesmo de outros países. Professores "famosos", como Paulo Freire, militantes como Aleda Guevara, políticos como Lula, artistas como Letícia Sabatella e simpatizantes diversos vinham ver como os sem-terra se organizavam ${ }^{17}$. Essas visitas Ihes davam "orgulho, as pessoas se motivavam, elas começavam a acreditar de novo no sonho que podia se tornar realidade" (Entrevista com Zanete, 25 março 2013).

Economicamente, um dos fatores que manteve a COOPAN em vida foi a decisão de diversificar a produção, a criação de animais tendo compensado as perdas nas lavouras. Entender que "não estávamos totalmente quebrados graças aos outros setores, nos levantava o moral" (Entrevista com Rivelino, 15 junho 2013). Em uma apresentação da cooperativa para jovens e professores de uma escola de ensino médio, Ana Paula, uma jovem sócia da COOPAN, explicava que "não foi sempre fácil. Nós conseguimos nos manter porque diversificamos a produção. Quando um setor ia mal, os outros compensavam. Se tivéssemos tido somente o arroz, poderíamos ter quebrado" (Apresentação de Ana Paula, 12 outubro 2013). Romeu conta que os cooperados dividiam cerca de $\$ 2.000$ reais, que eram as sobras das vendas, entre sessenta famílias. "Eu me lembro, não eram nem $\$ 40$ reais por família. Se era pra gente viver disso, a gente morria de fome. Os pais nos ajudavam ainda. Eles deram galinhas, vacas. Nós colocávamos tudo na caixa coletiva e alimentávamos primeiro as crianças" (Entrevista com Romeu e Elenice, 21 junho 2013).

A prestação de serviços foi o outro fator que permitiu equilibrar as finanças. Os quatro primeiros anos, os sócios deixavam a terra para irem fazer "bicos" em terras vizinhas, para completar o fim do mês. Todo esse dinheiro era dedicado à alimentação, mais ainda não era suficiente; os pais tinham que contribuir ${ }^{18}$. Em entrevista, muitos deles ressaltam que nessa época eles lutavam para saber quem iria comer

17 Lembramos que essa época, os anos 1990, foi o período no qual o MST recebeu o maior número de apoios da opinião pública internacional e nacional.

18 O único meio de transporte era uma Chevrolet 1976 que pertencia a Zanete. 
"a cabeça de porco da semana", pois não comiam a "verdadeira carne", o corpo do porco, que decidiam vender.

Com muita luta e pressão, os sócios conseguiram, finalmente, obter um crédito com o governo: "Ocupamos a Secretaria de Agricultura do estado e quebramos tudo. Era ou isso, ou morríamos de fome ${ }^{19}$ " (Entrevista com Zanete, 25 março 2013). Eles começaram então a receber subsídios agrícolas do INCRA para se alimentar e construir suas casas ${ }^{20}$. Mas ao invés de construir seus lares, os sócios investem na cooperativa, no começo comprando animais. As casas foram então um dos elementos sacrificados para o benefício da construção da cooperativa. Durante cerca de sete anos, eles viviam todos em algumas casas que já existiam quando chegaram. Entre dezoito e vinte-dois jovens, homens solteiros, viviam na casa onde hoje se encontra o escritório; outros quinze em quatro pequenas casas meio afastadas da agrovila e, para o resto, conseguiram economizar um pouco para construir as primeiras casas onde se amontoavam várias famílias. $\mathrm{Na}$ época, o INCRA dava $\$ 1.000$ reais por pessoa, quando ganhavam a terra. "Dava para comprar um teto de uma casa e só" (Entrevista com Zanete, 25 março 2013). Sozinhos, os sócios não podiam construir nada, mas eles tinham decidido que uma parte mínima dos lucros iria para a construção de uma casa de cada vez, motivo pelo qual demoraram sete anos para que todas as casas fossem construídas. Eles

19 Apesar desse retrato sombrio da relação do MST com o Estado, segundo Carter, quatro anos após a fundação da COOPAN, em 1998, o MST-Rio Grande do Sul efetuou ganhos sociais e políticos importantes com o governo: "The conservative onslaught under Cardoso's second term was largely offset in Rio Grande do Sul thanks to the 1998 election of Governor Olivio Dutra, the former PT mayor of Porto Alegre and a close MST friend" (Carter, 2015: 165).

20 Após um certo tempo, o governo criou o Programa Nacional de Fortalecimento da Agricultura Familiar (PRONAF), um programa de crédito para a pequena agricultura. "Tu empresta e quando tu reembolsa o primeiro pagamento, eles te dão o segundo automaticamente" (Entrevista com Zanete, 25 março 2013). Os cooperados sempre conseguiram pagar e nunca se endividaram desde que reembolsaram a dívida de $\$ 26.000$ reais. Segundo Carter, os anos 1990 no Rio Grande do Sul são palco de uma mudança de estratégia por parte do MST: "After the mid-1990s, MST land struggles in Rio Grande do Sul became more visibly entwined with a variety of other claims, such as demands for agricultural credits, housing subsidies, and access to schools and electricity, along with other public investments needed to shore up its settlements" (Carter, 2015: 168-169). 
preferiram investir no desenvolvimento da cooperativa ${ }^{21}$. Muitos criticaram essa decisão:

Vários saíram por esses motivos. Como que a cooperativa tem dinheiro para investir, mas não para distribuir aos sócios? Mas nós sempre cuidamos da saúde financeira da cooperativa antes da nossa. Sempre. Nós nunca tivemos títulos contestados, nós nunca fomos em conta aberta, nem em "giota" [emprestar dinheiro em instituições que não são bancos e com juros muito altos]. Nós sempre nos seguramos para nunca entrar nessas práticas. Nós fomos devagar na distribuição das sobras, sempre cuidando da saúde financeira do caixa. Sempre tivemos reservas em caso de emergência. Por exemplo, acabamos de ter uma perda de $\$ 30.000$ reais [roubo de um transformador elétrico] e ninguém sentirá isso no bolso. Nós nunca planejamos algo que não podíamos pagar (Entrevista com Airton, 23 março 2013).

Havia casos de cooperativas do MST que "comiam o capital" para distribuir aos sócios. A estratégia da COOPAN foi bem diferente: dar prioridade ao projeto comum em detrimento da qualidade de vida individual.

Nós nunca perdemos uma oportunidade de fazer um investimento produtivo sob pretexto que devíamos distribuir o dinheiro aos sócios. É uma diferença estratégica [com relação a outras cooperativas]. Nós sempre tivemos o princípio que nossos adiantamentos deviam vir dos resultados da produção. É um jeito de ver as coisas, de pensar. Outros podem decidir ir ao banco e emprestar (Entrevista com Emerson, 3 maio 2013).

21 Essa estratégia de desenvolvimento não é exclusiva da COOPAN e os efeitos sociais são geralmente os mesmos. Christoffoli escreve: "O grupo tendo optado pela estratégia de desenvolver inicialmente a estrutura produtiva ao detrimento de uma melhora social produziu um aumento da tensão que resultou da evolução das estruturas (meios de produção) e da situação social, ainda crítica, dos membros do coletivo. Isso gerou deserções de sócios insatisfeitos com a lenta evolução de suas condições sociais" (Christoffoli, 2000). Ainda segundo Christoffoli, essas primeiras deserções de sócios provocam um ajustamento entre a mão de obra disponível e o número de postos de trabalho tendo por resultado (inesperado) um aumento da produtividade. 
Ainda que essa estratégia possa ter sido um fator determinante do sucesso econômico da cooperativa, ela também representou uma decisão controversa. Foi, na verdade, o período em que a COOPAN perdeu o maior número de sócios.

A decisão de remeter a totalidade da ajuda recebida pelo INCRA para a cooperativa não fazia consenso. Levando-se em conta as condições materiais extremamente difíceis, certas famílias preferiram guardar uma parte da soma para seu consumo pessoal, o que gerou um conflito com aqueles que tinham decidido investir tudo na cooperativa. O sacrifício pessoal foi dos mais exigentes. Segundo Airton, "tu tem que ser solidário nesses momentos. Se tu não és solidário, tu não fica na cooperativa" (Entrevista com Airton, 23 março 2013). Com efeito, essa exigência muito alta de solidariedade não era compartilhada por todas as famílias, e muitas delas decidiram deixar a cooperativa. Airton tenta uma explicação:

Quando não temos nada a perder, como no acampamento, é fácil dar tudo e criar um espírito de solidariedade. Mas quando o econômico entra em jogo, quer dizer quando a gente começa a ter alguma coisa [como os recursos do INCRA], a gente logo vê pra quem a solidariedade não é emocional. Além de não respeitar a decisão coletiva [de investir o dinheiro] (Entrevista com Airton, 23 março 2013).

Um outro conflito entra em cena, nascido da tensão entre as convicções pessoais e os sacrifícios necessários. Para certas famílias, a convicção política não era suficientemente forte ao ponto de sacrificar tanto, nos níveis pessoal e econômico. Como sugere Airton, existe um segundo nível de análise ou um alicerce sobre o qual se estende o conflito, que é a relação entre o econômico e o político. Quando a situação econômica é catastrófica, "não temos nada a perder", é mais fácil sentir e agir em função de uma experiência política - que esteja fundada na solidariedade ou, ao contrário, em um ressentimento com 
relação ao outro'22. No entanto, assim que as condições materiais meIhoram, a situação se torna mais complicada.

Apoiando-se em especialistas da área, a COOPAN constatou que o setor mais rentável na época era o da horta. Porém, essa rentabilidade vinha do volume de vendas, e não da margem de lucro. Ao contrário, os lucros eram consideravelmente inferiores com relação às necessidades: "Não podíamos pensar em termos de uma família, duas famílias ou três famílias. Tínhamos que pensar para quarenta, cinquenta famílias. Então, tudo que tirávamos de lucro, individualmente, não representava nada" (Entrevista com Emerson, 3 maio 2013). Foi então que a COOPAN constatou um outro fator evidente e central: os setores deveriam gerar lucro em grande escala, quer dizer, com um retorno sobre o investimento suficiente para todas as famílias. Essa constatação lhes permitiu que se livrarem de setores que não atingiam certa escala de produção e um valor agregado adequado. Foi também nesse momento que perceberam que a maior margem de lucro decorria da integração do ciclo de produção, e que, por isso, tinham que acabar com os "intermediários". Podendo vender um produto final embalado com sua própria marca, lucrariam muito mais. A integração completa do ciclo de produção se concretizará mais tarde, mas o objetivo acabava de ser estabelecido. Eles decidiram conservar o arroz ${ }^{23}$ e os porcos, continuando o desenvolvimento da agroindústria.

Uma dificuldade consistiu em encontrar mercados para escoar os produtos. Por exemplo, eles mobilizavam dois ou três caminhões (emprestados de outros assentamentos) para vender porcos em uma dúzia de mercados da região. Às vezes, voltavam tendo vendido somente cinco porcos no total. Mas, pouco a pouco, "de conversa em conversa, conseguimos construir nossa reputação e aumentar nossa

22 Dentro de um contexto econômico difícil, a subida da extrema direita que culpa, por exemplo, os imigrantes, é um exemplo de reação política a uma situação de precariedade econômica.

23 No começo, eles produziam arroz que eles nem podiam consumir, pois não geravam lucros suficientes. 
parte de mercado"24 (Entrevista com Bosa, 3 maio 2013). Se vários tinham uma experiência com os porcos e o leite, ninguém sabia como plantar arroz.

Tivemos que aprender tudo! Começamos plantando arroz convencional, porque pensávamos que era mais fácil, mesmo se já tínhamos nossa horta orgânica. Tivemos bastante ajuda das outras cooperativas do Estado que vendiam arroz também. Hoje em dia, já faz quinze anos que plantamos arroz e ainda não sabemos como plantar direito. Todos esses anos, e ainda aprendemos (Entrevista com Bosa, 3 maio 2013).

Esses cinco a seis primeiros anos da COOPAN representaram uma prova suplementar do sofrimento físico - falta de alimentação, de habitação adequada, dificuldade para suprir várias necessidades materiais - e serviram de teste para a mente e para o corpo dos que duvidavam das vantagens do trabalho coletivo. Em revanche, para as pessoas cuja crença no trabalho coletivo estava consolidada há muito tempo, essa convicção não somente permaneceu intacta, mas se fortaleceu ainda mais. $O$ fato de se depararem com mais adversidades do que durante o acampamento teve como efeito solidificar as práticas de solidariedade e ajuda mútua. Como veremos nas seções seguintes, a orientação política do trabalho coletivo, fundada através da experiência do acampamento, precisou ser constantemente reafirmada para que se mantivesse o projeto de cooperativa.

\section{MEMÓRIA, POLÍTICA E ECONOMIA}

Nesta segunda parte do artigo, interrompo momentaneamente a história etnográfica dos fatos e análises em termos de eventos ocorridos cronologicamente. Essa decisão não decorre de minha metodologia; ela se explica pelo fato de que a memória de meus interlocutores perde repentinamente seu fio condutor nesse momento. Os anos passados

24 Para encontrar mercados, eles tinham simplesmente que se familiarizar com a região, pois a cooperativa fica perto de Porto Alegre, o maior mercado do Estado. 
nas casas dos pais, a decisão de deixar esse lar, cada evento durante o acampamento, as emoções vividas, as reflexões, a angústia e a esperança, é como se tudo isso estivesse cimentado sob a forma de uma trama narrativa nas mentes dos sócios da COOPAN. O começo da cooperativa também se beneficia dessa mesma memória límpida. As grandes dificuldades de organização da produção, as famílias amontoadas em algumas casas, a ajuda mútua, a fome, os conflitos e as famílias que deixam a cooperativa, a solidariedade, a falta de experiência, a incerteza de saber se o projeto era viável, todos esses fatos se encaixam em uma trama de eventos que parece tão clara e límpida como uma bela lembrança de infância. Essa clareza do passado se esfarela, porém, assim que se trata de contar o período do "meio", ou seja, a década entre os primeiros e os últimos anos de existência da COOPAN. Esse período que se estende, grosso modo, do começo dos anos 2000 até meados de 2010, aparece nebuloso na memória, como se esses anos se confundissem uns aos outros, a história de alguns eventos marcantes se sobrepondo à história cronológica. Tudo acontece como se esses anos fossem transcorridos na repetição, ou, em outras palavras, sem experiências políticas - no sentido de Lefort - significativas que permitissem construir uma trama narrativa completa e detalhada. Ao longo de minha pesquisa, tentei inúmeras vezes questionar os sócios sobre esse período. Mesmo tendo conseguido levantar alguns eventos importantes, a maior parte do tempo meus esforços foram em vão; um empenho visível por parte de meus interlocutores tentava reconstituir uma história, mas deviam se contentar com uma vaga lembrança de certos fatos salientes. Além disso, as conversas que pude flagrar, durante um fim de semana ou uma pausa de trabalho, sobre esse período, faziam referência a anedotas do tipo: as viagens à praia, o aniversário de fulano, a festa de tal comunidade, o carro que sicrano tinha anteriormente. Nada sobre a história da cooperativa em si.

Tomando certa distância com relação ao campo, analisando meus dados e procurando encontrar algo para preencher esse período de suas histórias, me deparei com uma "coincidência" de fatos que vinha a esclarecer essa curiosa transformação da memória. A COOPAN levou cerca de seis a sete anos para conseguir organizar bem suas linhas de 
produção e se estabilizar economicamente. Desde então, mesmo se os conflitos e obstáculos importantes ainda existiam, eles nunca foram significativos a ponto de colocar em dúvida o sucesso econômico da cooperativa. Infelizmente, não foi possível encontrar registros do progresso financeiro da cooperativa desde sua fundação, o que não me permitiu realizar uma comparação exata do período atual de estabilidade econômica com o período que corresponderia à "perda de memória" dos sócios. No entanto, perguntei inúmeras vezes, a vários sócios, se tinham lembrança exatamente de quando começaram a se considerar como "livres de grandes preocupações econômicas". A resposta unânime de todos foi entre seis e sete anos depois da fundação da cooperativa. Em outras palavras, podemos tirar a conclusão de que existe uma relação forte entre o atingimento de certo conforto material, devido à estabilidade econômica, e o começo da ausência de trama narrativa na memória dos sócios sobre esse período de suas vidas - período onde as experiências políticas parecem ausentes. Esse fenômeno incita uma análise da relação entre as dimensões econômicas e políticas da vida cotidiana.

Assim, ao invés de uma trama narrativa como apresentei até então, a história etnográfica que segue se orienta em função de fatos relevantes ou eventos marcantes que consegui destacar para esse período. Esses acontecimentos foram compilados de acordo com sua pertinência para a compreensão da relação dialética entre conflito e superação de conflito, que utilizo como quadro de análise para entender a dinâmica de construção da cooperativa e da consolidação da comunidade.

\section{TRANSIÇÃO PARA A AGROECOLOGIA ${ }^{25}$}

Sobre o período mais nebuloso da memória dos sócios, Emerson foi a pessoa mais lúcida em termos de análise geral das etapas es-

25 O termo agroecologia é muito polissêmico e sujeito a muitos debates quanto a sua definição. Eu utilizo a palavra, pois é o termo usado pelos sócios da COOPAN, mesmo se, na realidade, o arroz ainda não pode ser considerado agroecológico pelo simples fato de que as vacinas aplicadas aos animais não são orgânicas. Para mais informação a respeito do processo de produção agroecológico na COOPAN ver Escher, 2015. Para saber mais sobre agroecologia ver Altieri, 1995. 
truturantes da cooperativa. Ele foi o único capaz de indicar com precisão os eventos durante os quais "a cooperativa podia ter se desfeito". Sua história me permite dar forma a esses anos, completando-a com testemunhos de outros sócios. Emerson declara com muita convicção: "Nosso melhor acerto foi que todos os problemas que tivemos se transformavam em procedimento" (Entrevista com Emerson, 3 maio 2013). Assim, nesse período, um dos eventos conflitantes significativos na história da cooperativa - debatido exaustivamente entre todos os sócios - foi a decisão de começar a produzir arroz orgânico.

No começo, nós não tínhamos casa, somente o necessário para sobreviver. Conseguimos comprar um caminhão e passávamos veneno com a ajuda de um avião. Então, todos os gastos de produção estavam na plantação. Pouca experiência, pouco conhecimento, custo alto, depreciação enorme, produtividade fraca, anos com queda brusca de preços, sem contar as inundações, chuva de pedra, erros de manipulação, mau uso dos maquinários, tudo isso gerou uma péssima performance de produção que piorou ao longo dos anos. Nós tínhamos chegado a um ponto onde a atividade [do arroz convencional] tinha se tornado impossível economicamente (Entrevista com Emerson, 3 maio de 2013).

Essa explicação de Emerson resume os principais motivos estratégicos e econômicos que levaram a COOPAN a operar uma transição da produção de arroz convencional para arroz orgânico, decisão importante e momento de transformação na história da cooperativa ${ }^{26}$. A esses motivos se acrescenta o fato dos sócios ainda não disporem de uma agroindústria que permitisse a transformação do arroz. Eles produziam, mas deviam transportar o arroz até a cidade de Eldorado, a $200 \mathrm{~km}$, para secá-lo, armazená-lo, e em seguida trazê-lo de volta e empacotá-lo ${ }^{27}$. Esses fatores desmotivavam gradualmente os sócios com relação à produção de arroz. Inúmeras discussões e reuniões,

26 Atualmente, somente cerca de $5 \%$ dos assentamentos do MST em todo o Brasil produzem de maneira agroecológica, o que representa cerca de 75.000 indivíduos, dos 1.5 milhão de "membros" do Movimento (Panhke, 2015: 1098).

27 Mais tarde, a cooperativa regional COOTAP se estruturou melhor e criou os grupos de distribuição de arroz, o que facilitou muito o trabalho. 
onde várias alternativas eram longamente debatidas, ocorreram durante vários meses, mas nenhuma solução ao problema parecia consensual. Um primeiro fator, entretanto, acabou se contrapondo à falta de motivação. A COOPAN já possuía, na época, uma produção de hortas orgânicas ${ }^{28}$ em pequena escala ( 4 a 5 ha), vendida nos mercados públicos. Essa produção dava aos sócios a experiência prática sobre um outro jeito de se fazer agricultura, utilizando técnicas mais saudáveis para a saúde humana e o meio ambiente. Essa experiência agia na subjetividade de forma igualmente racional e emocional, mostrando na prática caminhos alternativos até então não imaginados. Foi igualmente nessa época que o MST começou a incentivar os assentamentos a produzirem de maneira orgânica.

Um "grande debate" acaba se impondo entre os sócios a respeito da alternativa mais realista e atraente, ou seja, a transição para uma produção de arroz orgânico. "Na época tinha bastante individualização: 'não funciona, você não sabe como fazer'. Isso criava um ambiente muito ruim" (Entrevista com Emerson, 3 maio 2013). Outro elemento decisivo que se acrescentava na equação, fazendo consenso entre os sócios, era o fato de que certas pessoas demonstravam sinais de intoxicação, e que os médicos identificavam, como uma possível causa, a exposição aos agrotóxicos. Certos indivíduos "tinham machucados que apareciam nos beiços e nas mãos. Era o veneno. Duas pessoas foram parar no hospital" (Entrevista com Emerson, 3 maio 2013). Na produção de arroz convencional, os sócios pagavam um pequeno avião para passar agrotóxicos nas lavouras, enquanto dois ou três indi-

28 Os sócios nem sempre plantaram hortas orgânicas. Isso começou depois de cerca de cinco anos, graças a Pelé, um sócio da COOPAN e técnico em agroecologia, que coordenou a transição do convencional para o orgânico. Eles tinham seis estufas, mas perderam as colheitas diversas vezes por conta de chuva ácida, às vezes já com encomendas grandes esperando. Oito pessoas trabalhavam na produção de uma grande variedade de legumes (brócolis, berinjela, cenoura, alface, pepino, abóbora, etc.). Eles entregavam uma vez por semana, aos sábados e terças-feiras. Tudo era orgânico. No começo, eles usavam adubo químico, mas não pesticidas. Pouco tempo depois, tudo se tornou agroecológico, uma produção para comercialização que durou sete anos. No que diz respeito ao seu próprio consumo de legumes, a cultura orgânica terminou em 2011, por falta de mão de obra. Eles possuíam um retorno financeiro relativamente razoável, mas não era suficiente, e os porcos geravam muito mais lucros. 
víduos ficavam nos campos para orientar o avião sobre aonde jogar o produto. Foi então que, durante debates muito animados e tensos, um sócio que defendia a transição intervém: "então os que querem continuar [com o convencional] têm que se colocar como voluntários para agitar a bandeira [utilizada pelos trabalhadores para orientar o avião]" (Entrevista com Airton, 23 março 2013). Ninguém se apresentou como voluntário e foi assim que começou a transição para uma produção de arroz orgânico. Mas, para realmente convencer os sócios, os dirigentes que defendiam o projeto, Pieri ${ }^{29}$, Pelé ${ }^{30}$ e Airton, tiveram que fazer bastante "educação popular" por meio de muitas discussões, formações, e assistindo documentários sobre os efeitos dos agrotóxicos ${ }^{31}$. "A gente acabou meio que impondo32", admitia Bosa. "Muitos ainda eram contra, porque eles pensavam que a gente ia quebrar a cara mais ainda" (Entrevista com Bosa, 3 maio 2013). A COOPAN foi um dos primeiros grupos de produtores a começar uma produção orgânica em grande escala no Estado do Rio Grande do Sul e no Brasil. Era, portanto, compreensível que os sócios estivessem céticos. Dinho, um sócio de um outro setor, relatou o ponto de vista de alguém que não era diretamente afetado cotidianamente no seu trabalho:

O único lugar onde nunca trabalhei foi as lavouras de arroz. Eu sei que no começo eles sofreram. Nas assembleias, tinha uns que queriam outros não. Como acontece em qualquer lugar. $A$ gente acabou votando. Mas por mim, esse tipo de decisão tem

29 Pieri faz parte da Direção da COOPAN e é um dos únicos a possuir um diploma em administração de cooperativas.

30 Rivelino conta que Pelé foi uma pessoa chave na transição, não somente na COOPAN, mas em todo o Estado, tanto para as hortas em geral como para o arroz. Ele possuía uma formação em agroecologia que poucos sem-terra tinham na época. "Ele mostrou que era possível fazer diferente” (Entrevista com Rivelino, 21 junho 2013).

31 Kombi, um dos dirigentes da COOPAN, dizia que durante o acampamento ainda não existia nenhuma discussão sobre as vantagens e desvantagens do orgânico com relação ao convencional. O debate só veio cerca de oito anos mais tarde com as discussões e as campanhas contra os Organismos Geneticamente Modificados (OGM).

32 A cooperativa teve até que proibir os sócios de utilizarem agrotóxicos em suas hortas pessoais em casa pois isso podia contaminar as lavouras coletivas. Os cooperados, na época, possuíam muito pouca documentação a respeito dos agrotóxicos. 
que ser o setor que tem que apresentar a proposição e depois encarar. Do que eles diziam, ia funcionar. la levar tempo, mas funcionaria. Eu que não estava nas lavouras, achava que a ideia era boa. Eu incentivava o projeto. Hoje em dia, ainda não está $100 \%$ mas eles conseguiram. Tu tem que confiar nos outros. Tu tem que ter confiança em quem vai fazer. Se tu não tem confiança, não avança. As pessoas podem ter os defeitos delas, mas são os que trabalham no setor em quem tu tem que ter confiança (Entrevista com Dinho, 24 junho 2013).

A transição não ocorreu sem obstáculos. Um investimento inicial era necessário e tiveram que fazer um empréstimo no banco. Na época, meados dos anos 2000, o público não era bem informado sobre produtos orgânicos e sua viabilidade econômica. Com medo de uma rejeição do pedido de empréstimo, os sem-terra omitiram ao banco que eles utilizariam o dinheiro para modificar a produção ${ }^{33}$. Além disso, eles não possuíam a estrutura necessária para armazenar o arroz e obter o certificado orgânico. Essa situação forçava-os a vender o arroz como sendo convencional, para não criar problemas com o banco. Eles então começaram a produzir orgânico em pequena escala, somente 6-7 ha ${ }^{34}$, mas vendendo como convencional. O mercado para produtos orgânicos era pouco desenvolvido nessa época, e o público com disposição para pagar mais caro por esse tipo de produto era muito restrito. Para garantir a venda de seu produto, os sem-terra vendiam sem lucro, às vezes abaixo do custo de produção; essa decisão asseguraria uma visibilidade e uma apreciação por parte dos consumidores que reconheciam uma qualidade superior. "Foi a meIhor demonstração que nós produzíamos por princípio, por convicção"

33 Os dois níveis de governo, federal e estadual, possuem vários programas para incentivar e consolidar a produção dos assentamentos. "O problema é que a gente nunca vê a cor do dinheiro, além de não ser suficiente", explica Bosa. "São 60 milhões de reais [programas de crédito à pequena agricultura que eles têm acesso], trinta do federal e trinta do estadual, mas depois de distribuídos, não sobra quase nada para as famílias. O melhor que eles oferecem são os empréstimos com juros baixos e alguns subsídios, mas é muito pouco. Nossa sorte é ter crédito no Banco do Brasil que nos permite emprestar $\$ 500.000$ reais ou até um milhão de reais se precisarmos" (Conversa de Bosa com os Uruguaios, 3 setembro 2013).

34 Eles constataram que a produção era mais fraca no orgânico, passando de 100 sacos/ha a $50-60$ sacos/ha. 
(Entrevista com Emerson, 3 maio 2013). Três anos depois, 100\% da produção era orgânica.

O último argumento que acabou convencendo definitivamente os sócios das vantagens da agricultura orgânica foi o aumento das sobras distribuídas para os associados. No primeiro ano (2001-2002), os sócios não conseguiram rentabilizar a transição por causa de produtividade e vendas muito fracas ${ }^{35}$. "Mas tivemos muito menos perdas econômicas, porque tínhamos reduzido os custos não comprando mais agrotóxicos, fertilizantes, etc. Isso se tornou outro argumento [a redução dos custos] para [convencer] os que [ainda] eram contra" (Entrevista com Bosa, 3 maio 2013). Esse argumento econômico foi totalmente determinante para convencer os céticos. Kombi, um dos dirigentes, explica o raciocínio: "Nos já sabíamos que os custos iam diminuir. A gente passava veneno de avião! Então, é por isso que eu falo que a parte econômica contou muito. A gente dizia: olha quanto nós gastamos de avião. Essa quantia a gente poderia redistribuir para as famílias" (Entrevista com Kombi, 13 junho 2013). Como Emerson era um "liberado" 36 " que cuidava das relações de produção entre os assentamentos, ele insistiu para que todos seguissem a mesma linha, dando o exemplo da COOPAN ${ }^{37}$. Isso ajudou muito a motivar os sócios céticos que viam, de repente, vários assentamentos do MST do Estado adotando as mesmas práticas.

A transição para a agroecologia representou um salto qualitativo significativo para a COOPAN. Simbolicamente e politicamente, ela demonstrava para todos os assentamentos do MST que uma alternativa à agricultura convencional dominada pelas multinacionais do agrone-

35 No começo, os sócios vendiam arroz orgânico, mas consumiam arroz convencional, pois não produziam o suficiente para se alimentar, além de vendê-lo.

36 O termo "liberado" é utilizado pelo MST para designar um militante sem-terra, escolhido pelos coordenadores ou liderança de uma comunidade sem-terra (acampamento ou assentamento), e cujas tarefas serão geralmente fora de sua comunidade.

37 As outras cooperativas que seguem na sequência são a COOPAT no Assentamento Lagoa do Junco, no município de Tapes, e a COAPRI no Assentamento Filhos de Sepé, em Viamão (Escher, 2015: 386). 
gócio era possível ${ }^{38}$. À imagem da COOPAN como modelo de gestão coletiva, se acrescentava a de "liderança ecológica". Isso é, aliás, um ponto central na estratégia política atual do MST em nível nacional, que insiste sobre o potencial de produtividade ao mesmo tempo econômico e agroecológico dos assentamentos (ver MST, 2013).

Do ponto de vista da construção da comunidade, uma vez a transição assegurada, assistimos à emergência de "um sentimento de orgulho". Na ocasião de uma visita de jovens alunos de uma escola de ensino médio à COOPAN, Reni explicou com muito orgulho o funcionamento da produção agroecológica. Depois da apresentação de Ana Paula a respeito do período de transição, Reni explicou bem entusiasmada: "E hoje pegamos o pó de arroz e damos aos porcos como cereais. O esterco é utilizado como adubo. Nada é perdido e podemos comprá-lo [o arroz] no mercado público de Porto Alegre" (Conversa de Reni com os jovens alunos, 10 outubro 2013). Visitas vêm regularmente constatar como a cooperativa funciona, a população local aprecia os produtos, e as festas comunitárias atraem miIhares de pessoas a cada ano. É importante ressaltar, para meu propósito, os três argumentos que acabaram convencendo os céticos. Primeiro, existia a falta de estruturação e organização da produção do arroz convencional, que não rendia mais suficientemente; depois foram as doenças de certos sócios e, por fim, o aumento das sobras redistribuídas aos associados pelo fato de terem baixado os custos de produção. O primeiro, e principalmente o último argumento, são os mais significativos, pois eles apontam novamente para a tensão entre os princípios políticos e os interesses econômicos pessoais na tomada de decisão dos sócios. Veremos que essas tensões aumentaram cada vez mais ao longo dos anos a ponto de expor explicitamente a questão da relação entre o econômico e o político, nos níveis coletivo e individual.

38 Escher explica que em 1994, ano de fundação da COOPAN, e com a criação da COOTAP em 1996, tudo tinha sido desenvolvido para a produção de arroz convencional. Hoje em dia, existem 1.300 famílias assentadas na região de Porto Alegre para um total de 18000 ha de terra, cujos 7000 ha são propícios à produção de arroz irrigado orgânico (Escher, 2015: 385). 


\section{O FRÁGIL EQUILÍBRIO ENTRE O INDIVIDUAL E O COLETIVO}

Voltemos à narrativa de Emerson. Uma vez que a cooperativa se estabilizou e se organizou economicamente em termos de produção e comercialização, o primeiro exemplo de conflito que poderia ter "desestruturado" a COOPAN remete à maneira de dividir alguns gastos cotidianos entre os sócios e a cooperativa. Inicialmente, a COOPAN costumava cobrir os gastos de uma lista de despesas regulares dos sócios, notadamente a conta de luz e o leite. "A cooperativa fazia qualquer coisa pelo sócio" (Emerson, 3 de maio 2013). Emerson disse que o problema surgiu quando certos sócios começaram a se queixar, por exemplo, de que algumas pessoas deixavam as luzes acesas durante a noite. Outras sempre se esqueciam de apagar as luzes de um setor. O que começou como queixas anedóticas insignificantes, rapidamente foi se ampliando: "sócios tratando os outros de tudo quanto é nome porque estavam desperdiçando dinheiro coletivo por caprichos pessoais ou estavam mostrando uma falta de responsabilidade com o grupo 39" (Emerson, 3 de maio 2013). De maneira similar à redistribuição da terra, a solução encontrada foi de implementar um "procedimento".

A primeira decisão que tomamos foi que a cooperativa não pagaria mais a conta de luz. Cada um pagaria sua própria conta. Estabelecemos uma média das contas de luz e incluímos no adiantamento. Então, ao invés de tirarmos dinheiro do adiantamento, nós acrescentamos mais dinheiro para que todos possam pagar suas contas. Resolveu um problemão! Depois dessa mudança, não teve mais queixas e mais ninguém deixou luz acesa inutilmente. Essa decisão serviu de lição para implantarmos uma série de procedimentos (Emerson, 3 de maio 2013).

39 Branford e Rocha relatam dois exemplos de problemas semelhantes em assentamentos do Nordeste. Nos dois casos, a associação do assentamento pagou a conta de eletricidade de todos os assentados. Não tendo como saber o consumo individual de cada casa, os assentados se queixam do consumo abusivo de uns e outros, o que acaba provocando conflitos importantes (Branford et Rocha, 2002: 103). 
Os sócios resolveram outro conflito, com relação ao leite e aos porcos, de maneira parecida. A cooperativa costumava distribuir seu próprio leite e porco gratuitamente aos sócios. Algumas pessoas começaram a se queixar de que alguns sócios iam pegar sua parte para em seguida revendê-la em vez de consumi-la. Os sócios decidiram calcular a média de custo dos porcos e do leite e redistribui-la aos sócios como adiantamento. Cada um passou a pagar para o leite e o porco. Problema resolvido:

Hoje em dia, tudo que os sócios pegam da cooperativa, eles têm que pagar. E nós sempre incluímos esses custos no adiantamento. Essa decisão foi extremamente educadora. Na época, essa decisão nos salvou! Essa decisão [...] responsabilizou as pessoas; deu-lhes ferramentas para administrar melhor a vida cotidiana. Por isso, hoje em dia, a cooperativa já não é mais responsável por manter as famílias financeiramente, porque as famílias se mantêm elas mesmas. [...] Isso teve o efeito de um enorme salto qualitativo do ponto de vista da gestão (Emerson, 3 de maio 2013).

O terceiro conflito importante, o que Emerson chama de "desentendimentos desestruturantes que tocam ao futuro da cooperativa", surgiu da perda gradual do controle das vendas. Por exemplo, o setor dos porcos vendia milho, cereais, ração de porco e porcos. O abatedor vendia carne, etc. Tudo era vendido separadamente. "Essa situação criava um mal-estar, uma insatisfação" e queixas surgiam:

Porque ele joga baralho no domingo de manhã em vez de estar vendendo porco? Não sei não, mas meu setor está aberto domingo de manhã! Quem sabe exatamente quantos quilos de carne nós tiramos desse porco? Ninguém exceto a pessoa que cortou! Isso criava uma insatisfação e uma desconfiança (Emerson, 3 de maio 2013).

Eles não tinham horário oficial de abertura dos setores e, por isso, clientes apareciam nas casas de alguns sócios um sábado à tarde para comprar carne, o que implicava trabalho extra para muitos sócios. 
Todos os sócios não tinham a mesma paciência e devoção; outros se queixavam da falta de seriedade e envolvimento com o coletivo. Como resolver o problema? "Depois de meses de discussão, brigas e debates, nós tomamos uma decisão. De agora em diante, os setores não serão mais responsáveis de nenhuma venda. Todas as vendas têm que ser feitas no escritório. Os setores só passariam as encomendas para o escritório40" (Emerson, 3 de maio 2013). Para Emerson, o efeito dessa decisão foi muito claro: "Foi uma mudança moralizadora. O efeito da moralização interna foi muito, muito, muito, muito grande, mais uma vez criado por um procedimento administrativo" (Emerson, 3 de maio 2013). Ele também nota que mesmo depois da implementação do procedimento, ainda havia setores que continuaram a vender seus produtos. Segundo Emerson, isso "demonstra que já tinha muitos vícios. E quando tem dinheiro envolvido, é muito pior. Essa mudança nos deu confiança, uma transparência administrativa muito grande" (Emerson, 3 de maio 2013). Para Emerson, "moralização" significa uma "grande transparência nas relações interpessoais. As pessoas de repente voltaram a fazer confiança uma a outra, porque elas sabiam que ninguém podia mais tirar proveito financeiramente do coletivo ${ }^{41}$ " (Emerson, 3 de maio 2013).

Através desses exemplos de conflitos, o que observamos aqui é a instauração de práticas que visam um equilíbrio entre a coletivização e a individualização. Nos dois primeiros exemplos mencionados, parece ocorrer um desequilíbrio a favor do coletivo, o que parece ter

40 A mudança é recente, tendo sido implantada em 2011. O sistema ainda não está bem rodado. Quando comento o fato de que as vendas agora são centralizadas, Dinho responde: "[risos] isso ainda acontece hoje. A cooperativa fecha às $11 \mathrm{~h} 30$ no sábado. Mas tem gente que chega depois e compra palha. Eles sabem onde fica a palha, eles pegam e deixam o dinheiro com a Rosane [mulher de Dinho. O casal mora ao lado de onde fica a palha]. Mas isso não está certo". Rosane acrescenta: "Eu nem sou sócia! Mas eu confio porque eles sempre compram aqui. Mas se alguém vê isso..." (Entrevista com Dinho e Rosane, 24 junho 2013).

41 Por motivos de comparação, Bleil relata os propósitos de Solange, uma militante da COPAVI, no Paraná: "O mais difícil foi sair da lógica do "eu"! Pensar a partir da ideia do "nós", "para o bem estar de todos os membros", mudar de mentalidade". "Para nós, foi essa mudança que foi a mais difícil" (Bleil, 2012: 233). 
como consequência uma deresponsabilização individual. Os indivíduos perdem a noção do valor de seus gestos, pois eles não enxergam os efeitos diretos destes na coletividade. Esse exemplo parece indicar que um excesso de coletivo pode acabar com o coletivo.

Em revanche, no último exemplo, observamos, ao contrário, o que parece ser um excesso de individualização. $O$ fato de cada setor vender seus próprios produtos tem como efeito desresponsabilizar o coletivo, deixando aos indivíduos envolvidos a escolha de assumir (ou não) essa responsabilidade. Uma desconfiança se instala como resultado. Nesse exemplo, o fato de coletivizar a atividade de vendas harmoniza uma prática cuja responsabilidade deve ser coletiva e não individual. Pela aplicação de "procedimentos", podemos "responsabilizar" ou "educar" os indivíduos, ou seja "moralizar" os "vícios", isto é, superar atitudes demasiadamente individualistas. Nos dois casos, não foram cursos teóricos sobre o individualismo liberal ou a coletivização socialista que fizeram com que as pessoas mudassem suas mentalidades e atitudes, mas sim, ações concretas e precisas que as levaram a entender - de maneira racional e sensível - que certos comportamentos, sejam eles individuais ou coletivos, não são adequados nem para os indivíduos, nem para o grupo.

Um outro exemplo do equilíbrio entre o individual e o coletivo, que merece atenção, foi o estabelecimento da ordem de construção e de distribuição das casas. Quando obtiveram os recursos do INCRA, os sócios decidiram colocar os recursos em comum e construir uma casa de cada vez. Porém, quem teria o privilégio de ser o primeiro a ver sua casa construída? Eles resolveram o problema decidindo proceder por sorteio, já tendo estabelecido o plano da agrovila, ou seja, a disposição das casas em forma oval. A primeira casa seria construída ao lado do escritório, que já possuía o sistema de esgoto, de água e eletricidade. Essas instalações deveriam ser estendidas na medida em que se construíssem as casas ${ }^{42}$. Em certos anos, não se construía ne-

42 As instalações deviam, logicamente, começar no escritório e se estender para as casas, uma decisão pragmática que, mesmo assim, se tornou objeto de vários debates, alguns 
nhuma casa; mas, geralmente, eles conseguiam distribuir entre duas e seis casas por ano às famílias ${ }^{43}$. Passaram-se mais de sete anos até que todas as trinta e três casas fossem construídas. Enquanto isso, os sócios moravam em várias famílias, nas casas que iam sendo levantadas. Perguntei a Fatima se tiveram problemas de "coabitação". Sua reposta foi reveladora do estado de espírito dos sócios:

Em casa, na verdade, ninguém é individualista por causa disso. Nós aprendemos a ter que dividir tudo. Antes dessa casa com o Romeu [a última antes que ela e sua família ganhassem sua própria casa], foram outras casas. A gente tinha sido escolhido bem antes, mas decidimos dar nosso lugar a outros que tinham mais necessidade: Zarpe, Romeu, Kombi [os dois últimos eram pais de família com crianças novas à época]. Foi umas três casas ou três rodadas que pulamos. Por exemplo, nas casas do centro [onde fica o escritório hoje e onde morava o maior número de pessoas juntas] tinha muita gente que não se entendia, e a gente pulava nossa vez. A ordem do sorteio e a ordem que foi seguida para instalar as famílias não foram as mesmas, porque os que tinham mais necessidade acabavam tendo suas casas antes (Entrevista com Fatima, 22 junho 2013).

Nesse conflito sobre a ordem de construção e distribuição das casas, a aplicação de uma solução intrinsicamente igualitária - o sorteio -, em uma situação onde as necessidades individuais são desiguais, tem por efeito fazer aparecer justamente, e com intensidade, uma situação política de injustiça. Essa situação de desigualdade reflete a forma de comunidade que os sócios desejam criar. O gesto de "pular a vez" mostra bem em quais princípios políticos os sócios se apoiam: igualdade, sim, mas não em detrimento de necessidades individuais diferentes. Em um grupo dotado de um espírito coletivo forte, a consequência é que os sujeitos reafirmam a orientação política da vida coletiva, dessa vez colocando concretamente limites à igualdade total das pessoas.

querendo que suas casas fossem construídas mais afastadas do escritório, mas antes que as dos outros.

43 Alguns sócios que possuíam certas economias reservadas, como Mauri, construíram suas casas antes dos outros, e a cooperativa os reembolsou mais tarde. 


\section{OS SALÁRIOS}

Os três próximos exemplos são a propósito dos "salários ${ }^{44 ", ~ q u e ~ o s ~}$ sócios chamam de "adiantamento", provavelmente o conflito mais duradouro e que atravessa toda a história da cooperativa ${ }^{45}$. O primeiro desses conflitos consistiu no fato de os salários serem contabilizados como um "adiantamento", uma "sobra". Se a cooperativa atingia uma boa performance econômica, ela produzia mais sobras, que eram então redistribuídas aos sócios.

Ao contrário, quando não ia bem, se a cooperativa não produzia sobras, o que tu tinha recebido [de sobras] se tornava uma dívida. Porque se a cooperativa não produz sobras, como que tu pode adiantar um dinheiro que não existe? Então, tinha bastante queixas. Nós perdemos várias famílias por conta desse mecanismo. Eu trabalhava mais, me esforçava mais, recebia mais, mas devia mais. Foi um erro. O que que nós fizemos? Dissemos que o adiantamento era um custo e não uma sobra. Foi extremamente significativo para a cooperativa. Então a mão de obra hoje não é considerada como uma redistribuição de sobras, mas como um custo de produção (Entrevista com Emerson, 3 maio 2013).

Em outras palavras, geralmente, em uma cooperativa, são as "sobras" ou os "excedentes" (os "lucros ${ }^{46 ") ~ q u e ~ s a ̃ o ~ d i s t r i b u i ́ d o s ~ a o s ~ s o ́ c i o s ~}$ sob a forma de salários ou "adiantamento". Esse "avanço" é contabilizado como um custo de produção, o que permite prever melhor e

44 Os sócios nunca chamam as rendas pessoais de "salários". Primeiro, porque isso representa, segundo eles, a sociedade do salariado criticada por Marx e, segundo, porque no jargão das cooperativas a renda dos sócios é chamada de "sobras" ou "excedentes". Quando perguntei se, independentemente das responsabilidades de um sócio na cooperativa, todos deveriam receber o mesmo salário, Airton respondeu: "Não é um salário. É como uma redistribuição mensal, mas não é um salário, é a redistribuição das sobras" (Entrevista com Airton, 23 março 2013).

45 Para experiências ao mesmo tempo similares e diferentes dos problemas relacionados aos salários, ver Chiariello e Eid, 2015: 91-96.

46 Os sócios não utilizam o termo "lucro", mas sim o termo "sobras" ou "excedentes" pelos mesmos motivos que não usam o termo "salário". 
se prevenir contra anos ruins onde não produzem sobras. Graças a esse novo "procedimento", a cooperativa é quem arca com a "dívida potencial", e não os sócios. É um outro exemplo de conflito entre individualização e coletivização, resolvido por um "procedimento" que fez balançar o equilíbrio do lado do coletivo.

Outro conflito com relação aos salários se materializou na decisão de distribuir uma renda mensal maior para as famílias. Antes dessa decisão, as famílias recebiam um montante relativamente baixo a cada mês, pois esperavam o fim do ano agrícola e os resultados financeiros antes de redistribuir de uma vez as eventuais sobras. Isso fazia com que os "pães-duros" aplicassem esse dinheiro no banco, enquanto que os "mão aberta" gastavam tudo de uma vez. Esses últimos vinham depois se queixar de que a cooperativa não distribuía dinheiro suficiente durante o ano. Eles então decidiram abolir esse "valor extra", e começaram a aumentar o adiantamento mensal. Em vez de esperar os resultados financeiros no fim do ano, eles decidiram calcular a média e distribuir as sobras mensalmente. Hoje em dia, eles têm uma "política estabelecida" de aumento gradual dos adiantamentos ao longo dos anos. A instauração dessa nova prática também teve um "efeito educativo" de "responsabilização individual". Eles tinham, nesse caso, que identificar uma prática que permaneceria individual, mas que educaria mais os sócios. A COOPAN sempre teve a ambição de ligar trabalho comum e vida privada dentro de uma relação pedagógica.

Em resumo, a problemática questão das sobras distribuídas aos trabalhadores talvez seja o conflito que mais gerou debates e descontentamentos ao longo dos anos. Dinho, por exemplo, diz que ele nunca concordou que todos ganhassem o mesmo salário. Ele acredita que os veteranos da cooperativa, os sócios que estão lá desde o começo deveriam ganhar "um pouco mais que os outros", que chegaram depois (como as esposas de alguns homens que se casaram mais tarde, ou a mão de obra de fora). Outros dizem que os "princípios de igualdade e justiça social" devem prevalecer, e defendem um salário igual para todos. Na prática, certos trabalhadores se irritam, pois eles têm a impressão de trabalhar mais que os outros pelo mesmo salário. De fato, 
existem sócios que só fazem o mínimo, ou que tentam tirar proveito de novas regras e procedimentos implantados. Outros excelentes trabalhadores dizem que sabiam disso desde o começo e que aceitaram essa realidade pelo bem do coletivo. Enfim, há também os sócios com deficiência física ou mental e que fazem parte da COOPAN desde o início. Os outros sócios os aceitaram no grupo sabendo que eles não conseguiriam trabalhar individualmente e que, mesmo dentro da COOPAN, eles nunca iriam contribuir tanto quanto um trabalhador com boa saúde. Por solidariedade, eles "carregam esses trabalhadores nas costas".

A remuneração individual dos sócios suscita um conflito que toca tanto no mérito pessoal quanto no mérito e na estima que têm pelos outros. Por um lado, a percepção que têm uns dos outros, às vezes distorcida pelos longos anos vividos juntos, fundamenta julgamentos que acabam prejudicando o espírito coletivo. Por outro lado, existem também pessoas (que pudemos observar) que não se dispõem a fazer mais do que o esforço mínimo, enquanto outras se dedicam de corpo e alma à cooperativa. Essa situação sempre existiu. Os dirigentes e outros sócios mais politizados sabiam desde o acampamento. Para eles, foi uma decisão consciente de aceitar esses indivíduos e de apostar que a cooperativa funcionaria assim mesmo. O problema não foi resolvido, e talvez não se resolva nunca de maneira definitiva. Como diz Bosa, "cada ano é diferente e nós sempre temos que nos reinventar"7". Talvez seja realmente o caso, pois o que apresentei aqui é, na realidade, o centro da divisão da comunidade COOPAN que poderíamos categorizar - a maneira ideal-tipo de Max Weber - como uma divisão entre coletivismo e individualismo. É importante ressaltar que essas categorias não são sinônimos de altruísmo e egoísmo. Elas refletem tendências, que sempre existiram, dentro da COOPAN. A tendência coletivista, levada por um grupo majoritário, reflete o comportamento

47 A orientação política que decorre do processo de subjetivação política não é algo que orienta indefinidamente o sujeito e o grupo. "Nós sempre temos que nos reinventar" significa dever revalidar ou reafirmar princípios políticos, às vezes transformando-os. Sob uma perspectiva teórica distinta, Bleil escreve que "o processo de formação da comunidade no âmbito de forjar um sentimento de pertença para com a "família COPAVI" sempre tem que ser [re]construído. Cada nova experiência comum representa um risco para a harmonia do grupo" (Bleil, 2012: 208). 
de indivíduos que sempre tiveram como prioridade o desenvolvimento e o sucesso do projeto coletivo. Essa atitude se repercute no esforço no trabalho. A tendência individualista representa um grupo minoritário e se caracteriza por indivíduos que "sempre seguiram a maioria", executando as decisões tomadas coletivamente. Esses indivíduos cumprem o trabalho deles; mas não têm como prioridade pessoal a significação política do projeto coletivo.

Essa divisão, é bom repetir, está presente desde o acampamento. A maioria dos sócios da COOPAN sempre soube que havia diferentes níveis de crença e devoção ao projeto coletivo por parte dos futuros sócios. É precisamente a consciência dessa divisão que faz com que, ao longo de toda sua história, encontremos um elemento constante e revelador do espírito de grupo dos sócios: a busca de um equilíbrio entre uma vida coletivizada e o respeito às diferenças, desejos e aspirações individuais; uma maneira de questionar a forma política da comunidade através de experiências coletivas e individuais - uma dialética do conflito; essa dialética se orienta em função de princípios políticos (forjados no tempo de acampamento) que precisam ser reafirmados constantemente.

\section{CONCLUSÃO}

Ao longo desse artigo, tentei construir uma história dos diferentes conflitos e das soluções implantadas para superá-los, colocando o foco nos acontecimentos que nos revelam a dinâmica de instituição de uma comunidade. Com efeito, a cada vez que se manifestam, esses conflitos colocam em cena a dimensão política da coexistência humana; eles interrogam, direta ou indiretamente, a forma da comunidade que os sócios da COOPAN tentam instituir. Os conflitos criam inúmeros debates, reuniões e discussões, que forçam uma parada da rotina de trabalho, a fim de abrir o olhar sobre a paisagem global da cooperativa e de seu modo de vida. Eles precisam refletir sobre as opiniões para tomar posição e justificá-la com argumentos. Quando surge um conflito, ele é percebido, segundo Emerson, como uma "oportunidade de crescer", uma ocasião de realmente refletir sobre o projeto comum. 
Mas, o que acaba realmente convencendo os sócios a tomarem uma decisão não é a acumulação de argumentos teóricos com relação às vantagens de tal ou tal escolha, mas sim, a implantação de "procedimentos", ou seja, práticas sociais que têm efeitos sensíveis e racionais sobre os sujeitos. Essas práticas "educam" e "responsabilizam", provocando uma reconstrução permanente da práxis.

\section{BIBLIOGRAFIA}

ALTIERI, Miguel. Agroecology: The Science of Sustainable Agriculture. Boulder: Westview Press, 1995.

BLEIL, Susana. Vie et luttes des sans terre au sud du Brésil: Une occupation au Paraná. Paris: Karthala, 2012.

BRANFORD, Sue; Jan ROCHA. Cutting the Wire: The Story of the Landless Movement in Brazil. London: Latin American Bureau, 2002.

CARTER, Miguel. "Origins and Consolidation of the MST in Rio Grande do Sul," in Carter, Miguel, ed. Challenging Social Inequality: The Landless Rural Workers Movement and Agrarian Reform in Brazil. Durham, NC: Duke University Press Books, 2015, p. 68-89.

CARTER, Miguel; Horacio Martins de CARVALHO. 2015b. "The Struggle on the Land", in Carter, Miguel (dir.) Challenging Social Inequality: The Landless Rural Workers Movement and Agrarian Reform in Brazil. Durham, NC: Duke University Press Books : 2015b, p. 229-273.

CHIARIELLO, Carlos Luis; Farid EID. "Dinâmica da gestão coletiva em uma cooperativa de reforma agrária do MST : Copavi”, in Mazin, Diogo Ângelo e Laís Santos. Questão Agrária, Cooperação E Agroecologia Volume 2. São Paulo: Expressão Popular., 2015, p. 77-99.

- Análise da Gestão de Cooperativas Rurais Tradicionais e Populares: Estudo de Casos na Cocamar e Copavi. Dissertação de mestrado, Programa de Pós-graduação em Engenharia de Produção, Universidade Federal de São Carlos, São Carlos, 2008. 
CHRISTOFFOLI, Pedro Ivan. "Comportamento ideológico e formas associativas de organização e gestão do trabalho em assentamentos da reforma agrária". 2000. On-line, https://www.researchgate.net/ publication/275100254_COMPORTAMENTO_IDEOLOGICO_E_ FORMAS_ASSOCIATIVAS_DE_ORGANIZACAO_E_GESTAO_DO_ TRABALHO_EM_ASSENTAMENTOS_DE_REFORMA_AGRARIA. Consultado $1^{\circ}$ setembro 2017.

. Eficiência econômica e gestão democrática nas cooperativas de produção coletiva do MST. Trabalho de conclusão de curso de especialização, Unisinos, São Leopoldo, 1998.

CONCRAB. Caderno de cooperação agrícola 5, São Paulo, 1998.

EID, Farid; Felipe ADDOR; Caio L. CHIARIELLO; Camila R. LARICCHIA, Alex KAWAKAMI. "Políticas de agroindustrialização em assentamentos da reforma agrária: uma análise do diálogo entre a prática das cooperativas do MST e as políticas governamentais", in Mazin, Diogo Ângelo e Laís Santos (dir.) Questão Agrária, Cooperação E Agroecologia - Volume 2. São Paulo: Expressão Popular, 2015, p. 135-170.

EID, Farid; Abraao PIMENTEL; Mariano R. SEVERINO; Carlos dos SANTOS. "Cadeias produtivas sob controle de famílias cooperadas do MST", in VII Congresso Latino-americano de Sociologia Rural. Annales, Quito, Equador, 2006, p. 1-18.

ESCHER, Sandra. "Proposta para a produção de arroz ecológico a partir de estudos de casos no RS e PR", in Mazin, Diogo Ângelo e Laís Santos. Questão Agrária, Cooperação E Agroecologia - Volume 2. São Paulo: Expressão Popular, 2015: p. 379-406.

HOLT-GIMENEZ, Eric. Campesino a Campesino. Oakland: Food First Books, 2008.

LEFORT, Claude. Essais sur le politique XIX-XXe siècles. Paris: Seuil, 1986.

MOVIMENTO DOS SEM TERRA (MST). 2013. Agrarian Program of the MST. São Paulo: Secretaria Nacional. 
1998.

NOVAES, Henrique Tahan; Joao Henrique PIRES; Douglas R. SILVA. "Cooperação e cooperativismo do MST de São Paulo: uma análise das ações do Estado capitalista que bloqueiam o potencial educativo do trabalho associado", in Mazin, Diogo Angelo e Laís Santos (dir.) Questão Agrária, Cooperação E Agroecologia - Volume 2. São Paulo: Expressão Popular, 2015, p. 99-134.

PAHNKE, Anthony. "Institutionalizing Economies of Opposition: Explaining and Evaluating the Success of the MST's Cooperatives and Agroecological Repeasantization." The Journal of Peasant Studies, Vol. 42. No. 6, 2015, p. 1087-1107.

PIMENTEL, Andréa E.B. Assentamentos da Reforma Agrária na Região do Pontal do Paranapanema e seus impactos econômicos e sociais. Tese de doutorado, Programa de Pós-graduação em Engenharia de Produção, Universidade Federal de São Carlos, São Carlos, 2004.

RANCIĖRE, Jacques. La Mésentente. Paris: Galilée, 1995.

RANGEL LOERA, Nashieli. A espiral das ocupações de terra. Campinas: Universidade Estadual de Campinas, 2006.

ROBLES, Wilder; Henry VELTMEYER. The Politics of Agrarian Reform in Brazil. New York: Palgrave Macmillan, 2015.

SEVERINO, Maria R. Organização e Processos de Trabalho em Cooperativas do MST: Debate Teórico no Contexto da Empresa Capitalistae daEconomia Solidária. Dissertação de mestrado, Programa de Pós-graduação em Engenharia de Produção, Universidade Federal de São Carlos, 2006.

VAZZOLER, Maria R. Cooperativismo em assentamentos de reforma agrária: a sobrevivência de cooperativas do MST no contexto capitalista. Tese de doutorado, Programa de Pós-graduação em Engenharia de Produção, Universidade Federal de São Carlos, 2004. 
WOLFORD, Wendy. This Land Is Ours Now: Social Mobilization and the Meanings of Land in Brazil. Durham NC: Duke University Press, 2010.

WRIGHT, Angus Lindsay; Wendy WOLFORD. To Inherit the Earth: The Landless Movement and the Struggle for a New Brazil. New York: Food First Books, 2003.

\section{ENTREVISTAS E NOTAS}

Apresentação de Ana Paula Bosa (Ana Paula), 12 outubro 2013

Conversa de Nilvo Bosa (Bosa) com os Uruguaios, 3 setembro 2013

Entrevista com Airton Rubenich (Airton), 25 março 2013

Entrevista com Nilvo Bosa (Bosa), 3 maio 2013

Entrevista com Carlos Asche (Dinho), 24 junho 2013

Entrevista com Emerson Giacomeli (Emerson), 3 de maio 2013

Entrevista com Fatima Milioransa (Fatima), 22 junho 2013

Entrevista com Anoïr Asche (Kombi), 13 junho 2013

Entrevista com Dionilson Marcon (Marcon), 23 junho 2013

Entrevista com Rivelino Fornasieri (Rivelino), 15 junho 2013

Entrevista com Romeu Marcon e Elenice Gracieli (Romeu e Elenice), 21 junho 2013

Entrevista com Wanderley Soares (Wanderlei), 4 setembro 2013

Entrevista com Luis Zanete (Zanete), 25 março 2013 